\title{
Political System in the Sovereign Kyrgyzstan
}

\author{
Dzhamilia Asanbekova1, Aigul Osmonova1, Islambek Abdyldaev², Edilbek Begaliev1, \\ Kutman Ashimov ${ }^{3}$, Kanykei Nurmamat kyzy¹, Omar Narbaev ${ }^{1}$, Salizhan Karimov', \\ Zhypargul Abdullaeva ${ }^{5 *}$ (i)
}

\author{
${ }^{1}$ Department of Criminal Law and Procedure, Osh State University, Osh, Kyrgyzstan \\ ${ }^{2}$ Department of Civil Law and Procedure, Osh State University, Osh, Kyrgyzstan \\ ${ }^{3}$ Finance and Juridical College, Osh State University, Osh, Kyrgyzstan \\ ${ }^{4}$ Department of History and Government Theory with Practice, Osh State University, Osh, Kyrgyzstan \\ ${ }^{5}$ Science and Research Department, Osh State University, Osh, Kyrgyzstan \\ Email: *jypar.science@oshsu.kg
}

How to cite this paper: Asanbekova, D., Osmonova, A., Abdyldaev, I., Begaliev, E., Ashimov, K., Nurmamat kyzy, K., Narbaev, O., Karimov, S., \& Abdullaeva, Z. (2021). Political System in the Sovereign Kyrgyzstan. Open Journal of Political Science, 11, 266272.

https://doi.org/10.4236/ojps.2021.112018

Received: February 12, 2021

Accepted: April 13, 2021

Published: April 16, 2021

Copyright $\odot 2021$ by author(s) and Scientific Research Publishing Inc. This work is licensed under the Creative Commons Attribution International License (CC BY 4.0).

http://creativecommons.org/licenses/by/4.0/

(c) (i) Open Access

\begin{abstract}
This article examines formation of the Kyrgyz Republic as a sovereign government, entering the path of parliamentarism and formation of a political system, development of the Kyrgyz parliament in the Soviet period, the transitional parliament called as the "Legendary parliament", and the period of independence, the Jogorku Kenesh. Emergence and development of international law in the national government system was analyzed where the government sovereignty in international relations actually existing as an independent government. Establishment of the sovereignty in Kyrgyzstan was initiated by the constitutional legislation of Soviet Kyrgyzstan based on significant development and within the framework of the Soviet constitutional legislation.
\end{abstract}

\section{Keywords}

Sovereignty, Political System, Parliamentarism, Party, Establishment, Jogorku Kenesh

\section{Introduction}

Sovereignty defined as a modern legal terminology characterizing the absence of restrictions and ability of the supreme power to independently determine and implement their will; the presence of their own institutions' power, the exercise of power without external influence, pressure; an exercise of powers reflected in the legal norms of national legislation (Shukbarov, 2018). Additionally, sovereignty is at the very center of the political and legal arrangements in the modern 
world (Jackson, 2007). The establishment and development of the "sovereignty" category are simultaneously related with the emergence and development of international law and the system of national governments, where the government sovereignty in international relations exists as an independent government with limits of the generally recognized norms of international law; it was also established in the Constitution of the Kyrgyz Republic, that the Kyrgyz Republic is a sovereign government (Abdykaimov \& Rakimbaev, 2014a; Abdykaimov \& Rakimbaev, 2014b). A sovereign government should be able to make its political, economic, and social decisions, and possess the moral obligation to protect and extend its citizens' political, economic, and social rights (Awdel et al., 2020). Kyrgyzstan integrated into Eurasian Economic Union, which is international organization of regional economic integration currently, including Russia, Kazakhstan, Belorussia, and Armenia (Sagynbekova, 2019).

Historically, the sovereignty of the Kyrgyz Republic as a government began almost 158 years ago. Kurmanjan Datka elected as a ruler in South Kyrgyzstan in the national elections; she was recognized as a political leader and politician, and was given the high title "Datka". Kurmanjan Datka left her historical mark by becoming the first woman ruler in the Kyrgyz people modern history. Her ascension to the throne became the clearest evidence of the profound democratic events; according to historians, to save the Kyrgyz people life, she agreed with Russia and made her wise decision.

The establishment of the sovereignty in Kyrgyzstan was initiated by constitutional legislation of Soviet Kyrgyzstan based on significant development and within the framework of the Soviet constitutional legislation as its component; the Constitution of the Kirghiz ASSR in 1929, the constitutions of the Kirghiz SSR in 1937, and 1978 were developed and adopted, respectively, based on the provisions according to the Constitution of the RSFSR in 1925, the constitutions of the USSR in 1924, 1936 and 1977 (Formation of the State Sovereignty of Kyrgyzstan, 2021).

On October 24, 1990, the Kirghiz SSR Supreme Soviet chairperson A. Masaliev signed a decree on the election of the first president in the country (Executive Committee of the Commonwealth of Independent Governments, 2021).

On December 15, 1990, the Supreme Soviet of the Kyrgyz SSR adopted the Declaration on State Sovereignty of the Republic of Kyrgyzstan, which became the most important event in the history of the country. From that moment, Kyrgyzstan began to be recognized as an independent sovereign state.

In Bishkek on 31.08.1991, by the resolution of the Supreme Council of the Republic of Kyrgyzstan, the Declaration on State Independence of the Republic of Kyrgyzstan was adopted, based on which the Republic of Kyrgyzstan is an independent, sovereign democratic government. The Constitutional Commission submitted to the Supreme Soviet of the Kyrgyz Republic the draft Constitution of the Kyrgyz Republic, which was adopted as a whole, and entered into force on 05.05.1993, after which presidential rule was established. In 1990, the Republic of 
Kyrgyzstan was called "An island of democracy". Among the democratic culture elements, the idea that democracy is preferable to any of its authoritarian regimes is considering a fundamentally stable democratic system (Haerpfer \& Kizilova, 2020). Freedom of speech was an integral part of public life in Kyrgyzstan, but as history shows, democratic values are gradually losing their force. "Political figures", forgetting about everything, began to openly fight for power, influence, and resources. There were political revolutions on March 24, 2005, and May 7, 2010, in Kyrgyzstan.

Kyrgyzstan became a member of the United Nations (UN), World Trade Organization, Organization for Security and Cooperation in Europe (OSCE), UNESCO, Commonwealth of Independent States (CIS), Collective Security Treaty Organization (CSTO), Shanghai Cooperation Organization (SCO), The Organization of Islamic Cooperation (OIC), the Organization for Economic Cooperation (ECO), the Cooperation Council of the Turkic-speaking States (CCTS), is taking integration steps into the Customs Union, the Eurasian Economic Community, establishing relations not only with the countries of the near and far abroad (Official Site of the President Kyrgyz Republic, 2021).

Traditionally, parliamentarism was initially established in the European part of the world. But it should be noted that in Kyrgyzstan its original form was started from the period of the most ancient social structures in the form of a council of elders (aksakals), a national assembly, a kurultai, at which decisions on the main issues of the life of society, tribe and clan were discussed and made (Kyrgyz Parliament History, 2021).

\section{Sovereignty Establishment}

Using their sacred right to be the bearer of sovereignty and the only source of government power in the Kyrgyz Republic, on April 6-7, 2010, the people of Kyrgyzs$\tan$ overthrew the anti-people regime of K.S. Bakiev. As a result of the national will, the government power passed to the interim government of the Kyrgyz Republic (Decree of Provisional Government of the Kyrgyz Republic, 2010).

Independence Day is the main public holiday in Kyrgyzstan, which was declared on August 31, 1991, after an extraordinary session of the Supreme Council of the Republic, which adopted the Declaration of Independence, a document that proclaimed Kyrgyzstan as a sovereign democratic government (Executive Committee of the Commonwealth of Independent Governments, 2021).

The people were distrustful of the interim government, so they had to make politically correct decisions, one of which was the transfer of most of the powers to the parliament and the prime minister. The people of Kyrgyzstan on June 27, 2010, used their constitutional right. The Kyrgyz Republic has taken a decisive course to eliminate the consequences of the usurpation of power, corruption, raider seizures of the previous rulers. Kyrgyzstan became a parliamentary republic. The new Government of the Kyrgyz Republic wanted to solve the accumulated problems through the parliamentary rule. 
Parties are one of the most important subjects of political relations. They have gone a long way in formation and evolution, are the product of the socio-political and socio-economic development of each specific country. Parties as an institution operating in the mass environment formed in Europe in the second half of the 19th century, during the formation of Western, bourgeois-type democracy. The etymology of the term party originated from Old French partie, based on Latin partiri, which means divide into parts.

Long before the formation of modern political parties, this term denoted groups of people competing with each other in the sphere of power or influence on power. The parties of the ancient world and the European Middle Ages were temporary associations to support certain individuals.

The highest legislative substance is the Jogorku Kenesh (parliament), which exercises legislative power and control functions within its powers. According to the 1993 Constitution, the Jogorku Kenesh consisted of two chambers: the Assembly of People's Representatives, which works in sessions and elected contingent on a representation of territorial interests, and the permanent Legislative Assembly, elected according to a representation of the entire population of the country.

\section{The Jogorku Kenesh Structure}

Since 2005, the Parliament of the Republic of Jogorku Kenesh is unicameral and consists of 120 deputies elected for a term of five years from party lists. The Parliament of Kyrgyzstan has priority in making important government decisions. The new parliament of the republic was elected on October 4, 2015, VI convocation. According to the results of the elections held on October 4, 2015, the Jogorku Kenesh of the Kyrgyz Republic of the VI convocation began its powers. In the history of parliamentarism, for the first time, a new form of the electoral process was developed and applied using modern technological equipment to identify voters and ensure automatic counting of votes. A feature of the past election campaign was the issue of compiling a list of voters, which was carried out by including in the list of citizens of the Kyrgyz Republic who had reached the age of 18 on voting day and who had passed biometric registration in the manner prescribed by law. As a result of the elections in which 14 political parties have participated, the following 6 political parties entered the parliament of the Kyrgyz Republic: political party "Social Democratic Party of Kyrgyzstan" 38 mandates; political party "Respublika-Ata Zhurt" 28 seats; political party "Kyrgyzstan" 18 mandates; political party "Progress" 13 mandates; the political party of State unity and patriotism "Bir Bol” 12 seats; political socialist party "Ata Meken” 11 seats.

By ethnic composition, the Jogorku Kenesh is represented by Kyrgyz, Russian, Uzbek, Dungan, Uighur, Kazakh, Tajik, Tatar nationalities, and the gender representations are respected too. To date, 228 political parties were registered on the website in 2020 of the central election committee (CEC) of the Kyrgyz Republic, but only a few of them were generally recognized (Figure 1). 


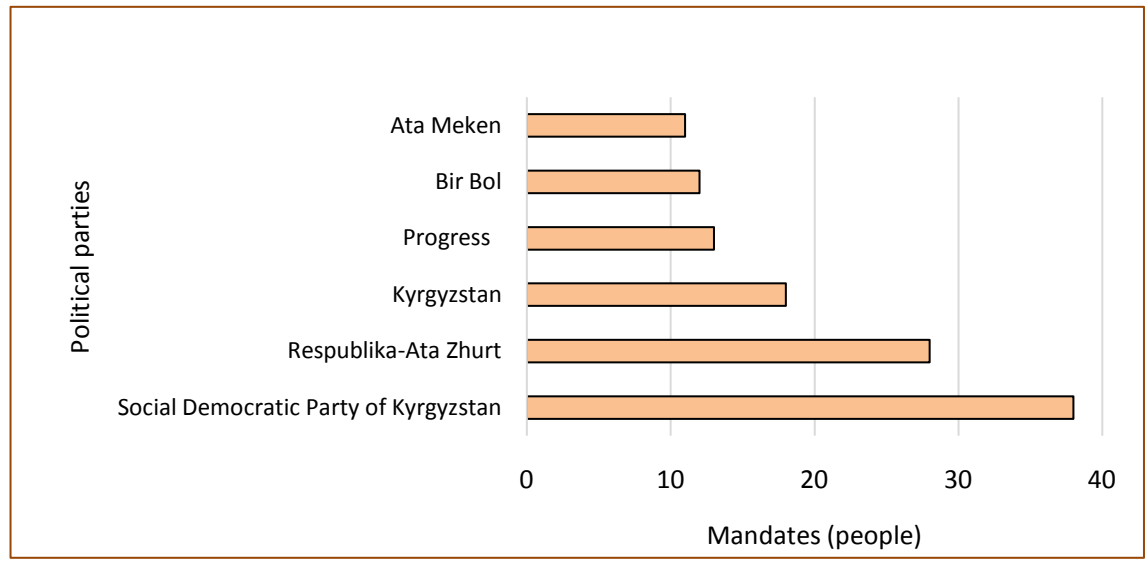

Figure 1. Political parties and mandates.

From the historiographic analysis of the party system development in Kyrgyzstan, political parties can be considered according to the following criteria:

- Long-term action;

- Full scale of sustainable local organizations, maintaining regular and varied links with the central leadership;

- Desire to seize power and exercise it, and not just influence it;

- Searching for support from the people, especially through elections.

Under the IRI program which works to improve the Kyrgyz Republic's democracy by helping in the development of a strong multi-party political system, and cultivating leaders by equipping youth and women with the skills to engage in the political process (Kyrgyzstan Political Process Program: IRI, 2021).

\section{Research Finding with Analysis}

The Central Executive Committee (CEC) was established on March 27, 1927 under the Abdykadyr Orozbekov chairmanship. Along with Imanaly Aidarbekov and Abdykadyr Orozbekov, the parliament of Kyrgyzstan in the Soviet years was also headed by Asanaly Tolubaev, Moldogazy Tokobaev, Torobay Kulatov, Sultan Ibraimov, Arstanbek Duisheev, Temirbek Koshoev, Tashtanbek Akmatov, Absamat Masaliyev, Mediakulov. Each of them made his own contribution to the formation of the Soviets as representative bodies of people's power on the territory of Kyrgyzstan (Kyrgyz Parliament History, 2021).

Following article 74 of the Constitution of the Kyrgyz Republic, the Jogorku Kenesh has the following powers:

1) Adopts a law on the appointment of a referendum;

2) Appoints the election of the President;

3) Introduces amendments to the Constitution;

4) Adopts laws;

5) Ratifies and denounces international treaties in the manner prescribed by law;

6) Resolves issues on changing the state borders of the Kyrgyz Republic;

7) Approves the republican budget and the report on its implementation; 
8) Resolves issues of the administrative-territorial structure of the Kyrgyz Republic;

9) Agrees to the appointment of the Prosecutor General, and agrees to bring him to criminal responsibility; gives consent to the dismissal of the Prosecutor General by at least one third of the total number of deputies of the Jogorku Kenesh;

10) Approves, by a majority of at least two-thirds of votes of the total number of deputies of the Jogorku Kenesh to dismiss the Prosecutor General in cases provided for by law (Ministry of Justice of the Kyrgyz Republic, 2021).

\section{Conclusion}

From the first days of independence, Kyrgyzstan has been considered a democratic country in the Central Asian region. In the 1990s, the country was called "an island of democracy in Central Asia"; in the next 10 years, the world community witnessed two revolutions that arose against the presidents who usurped power in the country. In 2010, the country announced the transition to a parliamentary form of government. Many argue that despite all of the above, Kyrgyzstan still fails to take its rightful place on the world stage. Based on the above, we conclude that the parliament is associated with such institutions of civil society as political parties and interested groups. The Kyrgyz Republic Parliament in Jogorku Kenesh is consisting of deputies elected for a term of five years party list. Parties are important subjects, which are initiating political relations, and have gone a long way of formation with evolution; they are the product of the socio-political and socio-economic development in each specific country.

\section{Conflicts of Interest}

The authors declare no conflicts of interest regarding the publication of this paper.

\section{References}

Abdykaimov, E. D., \& Rakimbaev, E. N. (2014a). The Psychological and Legal Features of Constitutional and Legal Strengthening of the Sovereignty the People of Kyrgyzstan. Matters of Russian and International Law, 10, 9-20.

Abdykaimov, E. D., \& Rakimbaev, E. N. (2014b). Constitutional and Legal Aspects Strengthening the Sovereignty of the People of Kyrgyzstan. Society and Law, 4, 318-321.

Awdel, z. M., Odel, n. M., \& Saadi, w. F. (2020). The rise of the Globalization and Its Effect on the Authonomy of State and Political Economy. Journal of Critical Reviews, 7, 998-1000. https://dx.doi.org/10.31838/jcr.07.06.171 https://doi.org/10.31838/jcr.07.06.171

Decree of Provisional Government of the Kyrgyz Republic (2010). On the Transfer of Power to the Provisional Government of the Kyrgyz Republic. Bishkek 07.04.2010.

Executive Committee of the Commonwealth of Independent Governments (2021). August 31 Is Independence Day of the Kyrgyz Republic. URL (last checked 6 February 2021).

https://cis.minsk.by/news/16021/31 avgusta - den nezavisimosti kyrgyzskoj respubli $\underline{\mathrm{ki}}$ 
Formation of the State Sovereignty of Kyrgyzstan (2021). Jurisprudence Articles. URL (last checked 6 February 2021). https://articlekz.com/article/10329

Haerpfer, C. W., \& Kizilova, K. (2020). Values and Transformation in Central Asia. In A. Mihr (Ed.), Transformation and Development (pp. 7-28). Cham: Springer. https://doi.org/10.1007/978-3-030-42775-7 2

Jackson, R. (2007). Sovereignty: The Evolution of an Idea (200 p.). Cambridge: Polity. ISBN: 978-0-745-62338-2.

Kyrgyzstan Political Process Program: IRI (2021). News and Information. URL (last checked 12 February 2021).

https://www.usaid.gov/kyrgyz-republic/fact-sheets/kyrgyzstan-political-processes-prog $\underline{\text { ram-iri }}$

Kyrgyz Parliament History (2021). URL (last checked 27 February 2021). http://www.kenesh.kg/ru/38/article/print/

Ministry of Justice of the Kyrgyz Republic. (2021). Constitution of the Kyrgyz Republic. URL (last checked 27 February 2021). http://cbd.minjust.gov.kg/act/view/ru-ru/202913?cl=ru-ru

Official Site of the President Kyrgyz Republic (2021). History. URL (last checked 27 February 2021). http://www.president.kg/ru/kyrgyzstan/istoriya

Sagynbekova, L. (2019). International Labour Migration in the Context of the Eurasian Economic Union: Issues and Challenges of Kyrgyz Migrants in Russia. International Labour Migration in the Context of the Eurasian Economic Union: Issues and Challenges of Kyrgyz Migrants in Russia. Working Paper No. 39.

Shukbarov, D. (2018). State Sovereignty: Modern Threats. Student Science Issues, 6, 3441. 